\title{
A prospective descriptive study of evaluation of menstrual disorders in thyroid dysfunction
}

\author{
Durgavathi Kothapalli, Kamesari Kolluru*
}

Department of Obstetrics and Gynecology, Konaseema Institute of Medical Science Amalapuram, Andhra Pradesh, India

Received: 26 April 2021

Accepted: 28 May 2021

*Correspondence:

Dr. Kamesari Kolluru,

E-mail: k.kameswari@gmail.com

Copyright: () the author(s), publisher and licensee Medip Academy. This is an open-access article distributed under the terms of the Creative Commons Attribution Non-Commercial License, which permits unrestricted non-commercial use, distribution, and reproduction in any medium, provided the original work is properly cited.

\begin{abstract}
Background: Menstrual irregularities are common with thyroid disorders. It has been reported that hyperthyroidism the most common manifestation is simple oligomenorrhea and hypothyroidism usually is associated with polymenorrhea. Present study has been designed to evaluate the menstrual and endometrial patterns in women with thyroid disorders in costal Andhra Pradesh.

Methods: During the study period of two years and ten months we have enrolled 110 patients with clinical presentation of thyroid disorder with menstrual irregularities as per our study criteria. Based on report patients were divided in to three groups, hyperthyroid, hypothyroid and subclinical hypothyroidism. Based on abnormal menstrual pattern patients were divided in to menorrhagia, oligomenorrhea, polymenorrhea, and amenorrhea groups. Endometrial biopsy was taken from women in perimenopausal age group and histopathological examination was done to know the pattern of endometrium.

Results: Subclinical hypothyroidism was present in $24(21.81 \%)$ patients, hypothyroidism was present in $52(47.27 \%)$ patients and hyperthyroidism was present in 34 (30.90\%) patients. amenorrhea was present in $26(23.63 \%)$ patients, oligomenorrhea was present in $12(10.90 \%)$ patients, Intermenstrual bleeding was present in $2(1.81 \%)$ patients, Menorrhagia was present in $44(40 \%)$ patients which was most common type of menstrual disorder and Polymenorrhagia was present in $26(23.63 \%)$ patients.

Conclusions: Hypothyroidism is most common thyroid disorder followed by hyperthyroidism and subclinical hypothyroidism is least common. We have found that menstrual irregularities are more common in hypothyroid patients than hyperthyroid. Menorrhagia and Polymenorrhagia is more common than amenorrhoea and oligomenorrhea in hypothyroid patients.
\end{abstract}

Keywords: Histopathology, Menstrual disorders, Thyroid dysfunction

\section{INTRODUCTION}

As per the report of multicentric study by world health organisation the prevalence of menstrual irregularities was varied from $8 \%$ to $27 \%$. $^{1}$ Nitika et al from India have reported that Nearly $1 / 10^{\text {th }}(10.9 \%)$ of the women had menstrual problems. ${ }^{2}$ Von Basedow in 1840 has described that thyroid disorder is associated with menstrual irregularities. ${ }^{3}$ Normal menstrual cycle depends upon hypothalamic-pituitary-gonadal axis and its constituents like gonadotropins follicle-stimulating hormone (FSH) and luteinizing hormone (LH) and sex steroid hormones like progesterone and oestrogens. This system is closely associated with hypothalamic-pituitary-gonadal axis and relation between thyroid function and reproductive physiology is complex. Both hyper- and hypothyroidism are associated with greater prevalence of menstrual disturbances compared with euthyroid women. ${ }^{4,5}$ It has been reported that hyperthyroidism the most common manifestation is simple oligomenorrhea and hypothyroidism usually is associated with polymenorrhea. ${ }^{6}$ Jacobson et al from USA has reported that circulating thyroid hormone concentrations were associated with subtle differences in menstrual cycle 
function outcomes, particularly sex steroid hormone levels in healthy women. ${ }^{5}$ Ajmani et al from Delhi has reported that In patients with menstrual disorders, $44 \%$ had thyroid disorders in which subclinical hypothyroidism was prevalent in $20 \%$, overt hypothyroidism in $14 \%$, and overt hyperthyroidism in $8 \%$ of the women. ${ }^{7}$

Kakuno et al from Japan have concluded that the prevalence of menstrual disturbances, including secondary amenorrhea, hypomenorrhea, oligomenorrhea, hypermenorrhea, polymenorrhea and irregular menstrual cycle, in patients with various thyroid diseases, such as hyperthyroidism, hypothyroidism, euthyroid patients with chronic thyroiditis, painless thyroiditis and thyroid tumor, did not differ from that in healthy controls. ${ }^{8}$ Based on above literature present study has been designed to evaluate the menstrual and endometrial patterns in women with thyroid disorders in costal Andhra Pradesh.

\section{METHODS}

\section{Place of study}

Present study has been conducted in the department of obstetrics and gynaecology Konaseema Institute of Medical Science Amalapuram Andhra Pradesh India.

\section{Duration of study}

This study has been conducted from March 2018 to January 2021.

\section{Type of study}

This was a prospective descriptive study.

\section{Selection of patients}

All patients with clinical presentation of thyroid dysfunction attending gynaecology outpatient department were selected for study based on inclusion and exclusion criteria.

\section{Inclusion criteria}

Age 16 to 45 years, thyroid dysfunction with abnormal uterine bleeding.

\section{Exclusion criteria}

Patients with poly cystic ovarian disease, endometriosis, ovarian cyst, uterine fibroid, polyps, malignant endometrial and cervical tumours. Pregnancy. Pelvic inflammatory disorder, bleeding disorder

\section{Sample size}

Sample size was calculated to be 110 by considering prevalence $27 \%$ from previous study and using formula:

$$
n=\frac{Z^{2} p(1-p)}{d^{2}}
$$

Where $\mathrm{n}$ is the sample size, $\mathrm{Z}$ is the statistic corresponding to level of confidence, $\mathrm{P}$ is expected prevalence.

\section{Method of data collection}

During the study period of two years and ten months we had enrolled 110 patients with clinical presentation of thyroid disorder with menstrual irregularities as per our study criteria. A detailed history of patient was taken with reference to thyroid dysfunction and menstrual irregularities like amount of bleeding, pattern, onset and duration of bleeding. A detailed demographic history of patient was also obtained. All patients were examined clinically regarding gynaecological and general examination. Routine investigation was done in all patients like hemoglobin, BT, CT, thyroid function like free T3, free T4 and TSH etc. For estimation of thyroid hormone we used radioimmunoassay and solid phase two-site immunoradiometric assay technique. Reference level of free $\mathrm{T} 3=2.45: 4.25 \mathrm{pg} / \mathrm{ml}$, free $\mathrm{T} 4=0.58: 1.64 \mathrm{ng} / \mathrm{ml}$ and $\mathrm{TSH}=0.34-5.60 \mathrm{uIU} / \mathrm{mL}$. Based on report patients were divided in to three groups, hyperthyroid, hypothyroid and subclinical hypothyroidism. Based on abnormal menstrual pattern patients were divided in to menorrhagia, oligomenorrhea, polymenorrhea, and amenorrhea groups. Endometrial biopsy was taken from women in perimenopausal age group and histopathological examination was done to know the pattern of endometrium.

For diagnosis of thyroid and menstrual disorder standard protocol was followed. ${ }^{9,10}$

\section{Statistical analysis}

Data were recorded in excel sheet and statistical Analysis was done with software SPSS-14 version. Data were calculated as percentage and proportions.

\section{RESULTS}

In present study as per selection criteria and sample size calculation 110 patients were enrolled.

Table 1: Demography of patients.

\begin{tabular}{|llll|}
\hline Variables & & Number & Percentage \\
\hline \multirow{3}{*}{$\begin{array}{l}\text { Age } \\
\text { (years) }\end{array}$} & Less than 20 & 5 & 4.45 \\
\cline { 2 - 4 } & 21 to 30 & 45 & 40.90 \\
\cline { 2 - 4 } & 31 to 40 & 30 & 27.27 \\
\cline { 2 - 4 } $\begin{array}{l}\text { Marital } \\
\text { status }\end{array}$ & unmarried 40 & 30 & 27.27 \\
\cline { 2 - 4 } Parity & married & 18 & 16.36 \\
\hline \multirow{2}{*}{ Nulliparous } & 12 & 83.63 \\
\cline { 2 - 4 } & Multiparous & 98 & 10.90 \\
\hline
\end{tabular}


Regarding age of patients, $5(4.45 \%)$ patients were below 20 years, $30(27.27 \%)$ patients were between 21 to 30 years, $45(40.90 \%)$ patients were between 31 to 40 years and $30(27.27 \%)$ patients were above 40 years. Among all patients $18(16.36 \%)$ patients were unmarried and 92 $(83.63 \%)$ patients were married. Regarding parity of patients, $12(10.90 \%)$ patients were nulliparous, and 98 $(89.09 \%)$ are multiparous.

Table 2: Distribution of thyroid disorder in study group.

\begin{tabular}{|llll|}
\hline Variables & & Number & Percentage \\
\hline \multirow{2}{*}{$\begin{array}{l}\text { Thyroid } \\
\text { disorder }\end{array}$} & $\begin{array}{l}\text { Subclinical } \\
\text { hypothyroidism }\end{array}$ & 24 & 21.81 \\
\cline { 2 - 4 } & hypothyroidism & 52 & 47.27 \\
\cline { 2 - 4 } & hyperthyroidism & 34 & 30.90 \\
\hline
\end{tabular}

As per Table 2, regarding thyroid disorder in study group, subclinical hypothyroidism was present in $24(21.81 \%)$ patients, hypothyroidism was present in $52(47.27 \%)$ patients and hyperthyroidism was present in $34(30.90 \%)$ patients.

Regarding distribution of menstrual disorder in study group, amenorrhea was present in $26(23.63 \%)$ patients, oligomenorrhea was present in $12(10.90 \%)$ patients, intermenstrual bleeding was present in $2(1.81 \%)$ patients, menorrhagia was present in $44(40 \%)$ patients which was most common type of menstrual disorder and polymenorrhagia was present in $26(23.63 \%)$ patients.
Table 3: Distribution of menstrual disorder in study group.

\begin{tabular}{|c|c|c|c|}
\hline Variables & & Number & Percentage \\
\hline \multirow{5}{*}{$\begin{array}{l}\text { Menstrual } \\
\text { disorder }\end{array}$} & Amenorrhea & 26 & 23.63 \\
\hline & Oligomenorrhea & 12 & 10.90 \\
\hline & $\begin{array}{l}\text { Intermenstrual } \\
\text { Spotting }\end{array}$ & 2 & 1.81 \\
\hline & Menorrhagia & 44 & 40 \\
\hline & Polymenorrhagia & 26 & 23.63 \\
\hline
\end{tabular}

Table 4: Distribution of study subject based on endometrial biopsy.

\begin{tabular}{|c|c|c|c|}
\hline Variables & & Number & Percentage \\
\hline \multirow{4}{*}{$\begin{array}{l}\text { Endometrial } \\
\text { biopsy }\end{array}$} & $\begin{array}{l}\text { Simple } \\
\text { hyperplasia } \\
\text { without atypia }\end{array}$ & 12 & 10.90 \\
\hline & $\begin{array}{l}\text { Complex } \\
\text { hyperplasia } \\
\text { without atypia }\end{array}$ & 8 & 7.27 \\
\hline & $\begin{array}{l}\text { Secretary } \\
\text { endometrium }\end{array}$ & 44 & 40 \\
\hline & $\begin{array}{l}\text { Proliferative } \\
\text { phase }\end{array}$ & 8 & 7.27 \\
\hline
\end{tabular}

Secretary endometrium was most common histopathological presentation present in 44 (40\%) patients; complex hyperplasia without atypia was present in $8(7.27 \%)$ patients, simple hyperplasia without atypia was present in 12 patients and 8 patients have proliferative endometrium in histopathology.

Table 5: Distribution of thyroid disorders based on the menstrual irregularities of study group.

\begin{tabular}{|c|c|c|c|c|c|c|c|c|c|c|c|}
\hline \multirow{3}{*}{ Variables } & \multicolumn{11}{|c|}{ Menstrual Irregularities } \\
\hline & & \multicolumn{2}{|c|}{ Amenorrhea } & \multicolumn{2}{|c|}{ Oligomenorrhea } & \multicolumn{2}{|c|}{$\begin{array}{l}\text { Intermenstrual } \\
\text { spotting }\end{array}$} & \multicolumn{2}{|c|}{ Menorrhagia } & \multicolumn{2}{|c|}{ Polymenorrhagia } \\
\hline & & $\mathbf{N}$ & $\%$ & $\mathbf{N}$ & $\%$ & $\mathbf{N}$ & $\%$ & $\mathbf{N}$ & $\%$ & $\mathbf{N}$ & $\%$ \\
\hline \multirow{3}{*}{$\begin{array}{l}\text { Thyroid } \\
\text { disorder }\end{array}$} & $\begin{array}{l}\text { Subclinical } \\
\text { hypothyroidism }\end{array}$ & 5 & 19.23 & 2 & 16.67 & 1 & 50 & 16 & 28.57 & 6 & 23.07 \\
\hline & hypothyroidism & 16 & 61.53 & 5 & 41.66 & 1 & 50 & 24 & 52.17 & 16 & 61.5 \\
\hline & hyperthyroidism & 5 & 19.53 & 5 & 41.66 & 0 & & 6 & 13.04 & 4 & 15.38 \\
\hline
\end{tabular}

Table 6: Distribution of thyroid disorders based on the endometrial biopsy of study group.

\begin{tabular}{|c|c|c|c|c|c|c|c|c|c|}
\hline \multirow{3}{*}{ Variables } & & \multicolumn{8}{|c|}{ Endometrial biopsy } \\
\hline & & \multicolumn{2}{|c|}{$\begin{array}{l}\text { Simple hyperplasia } \\
\text { without atypia }\end{array}$} & \multicolumn{2}{|c|}{$\begin{array}{l}\text { Complex hyperplasia } \\
\text { without atypia }\end{array}$} & \multicolumn{2}{|c|}{$\begin{array}{l}\text { Secretary } \\
\text { endometrium }\end{array}$} & \multicolumn{2}{|c|}{ Proliferative phase } \\
\hline & & $\mathbf{N}$ & $\%$ & $\mathbf{N}$ & $\%$ & $\mathbf{N}$ & $\%$ & $\mathbf{N}$ & $\%$ \\
\hline \multirow{3}{*}{$\begin{array}{l}\text { Thyroid } \\
\text { disorder }\end{array}$} & $\begin{array}{l}\text { Subclinical } \\
\text { hypothyroidism }\end{array}$ & 2 & 16.67 & 00 & & 10 & 22.7 & 2 & 25 \\
\hline & hypothyroidism & 6 & 50 & 8 & 100 & 32 & 72.4 & 6 & 75 \\
\hline & hyperthyroidism & 4 & 33.3 & 0 & & 2 & 4.54 & 0 & \\
\hline
\end{tabular}


Regarding distribution of thyroid disorders based on the menstrual irregularities of study group amenorrhea was more common in hypothyroidism patients $(61.53 \%)$ and equally present in subclinical hypothyroidism and hyperthyroidism patients $(19.23 \%)$. Oligomenorrhea was equally present $5(41.66 \%)$ in hypothyroidism and hyperthyroidism patients. Intermittent spotting was less common and present in one patient in hypothyroidism and subclinical hypothyroidism patients. It is absent in hyperthyroidism patient. Menorrhagia is most common in hypothyroidism patients (52.17\%). Menorrhagia was present in $16(28.57 \%)$ subclinical hypothyroidism patients. Polymenorrhagia was present in $6(23.07 \%)$ subclinical hypothyroidism, $16 \quad(61.5 \%)$ subclinical hypothyroidism and $4(15.38 \%)$ hyperthyroidism patients (Table 5).

Regarding histopathological finding of endometrium in perimenopausal women simple hyperplasia without atypia was present in $2(16.67 \%)$ patients with subclinical hypothyroidism, $6(50 \%)$ patients with hypothyroidism and $4(33.3 \%)$ patients with hyperthyroidism. Complex hyperplasia without atypia was absent in patients with subclinical hypothyroidism, $8(100 \%)$ patients with hypothyroidism and absent in hyperthyroidism. Secretary endometrium was present in $10(22.7 \%)$ patients with subclinical hypothyroidism, $32(72.4 \%)$ patients with hypothyroidism and $2(4.54 \%)$ patients with hyperthyroidism. Proliferative endometrium was present in $6(75 \%)$ patients with hypothyroidism and $2(25 \%)$ patients with subclinical hypothyroidism (Table 6).

\section{DISCUSSION}

Thyroid status of women has greater influence on reproductive life and it is established that menstrual disturbance is associated thyroid dysfunction. Present study has been designed to evaluate the menstrual and endometrial patterns in women with thyroid disorders in costal Andhra Pradesh. We have enrolled 110 patients as per selection criteria and sample size calculated statistically. Most of the patients were in $3^{\text {rd }}$ and $4^{\text {th }}$ decade of life and married. It is more common in multiparous. This is supported by the study of Khatiwada et al and Ramya et al. ${ }^{11,12}$

In our study hypothyroidism $(47.27 \%)$ is most common thyroid disorder followed by hyperthyroidism (30.90\%) and subclinical hypothyroidism $(21.81 \%)$ is least common. Ajmani et al have reported that hypothyroidism was the commonest abnormality as seen in $34 \%$ cases in the study group, out of which $20 \%$ had subclinical hypothyroidism. ${ }^{13}$ This finding support our study. Our finding is also supported by the work of Güngör et al. ${ }^{14}$

In present study menorrhagia and polymenorrhagia are more common than amenorrhoea and oligomenorrhea which corroborates with the study of Padmaleela et al and Pahwa et al. ${ }^{15,16}$ Regarding histopathology of endometrial biopsy of thyroid disorder patients presented with menstrual dysfunction secretory endometrium was most common histopathological presentation present in $40 \%$ patients, complex hyperplasia without atypia was present in $7.27 \%$ patients, simple hyperplasia without atypia was present in $10.90 \%$ patients and $7.27 \%$ patients had proliferative endometrium in histopathology. This finding is supported by the work of Gorla et al and Verma et al. ${ }^{17,18}$

In present study we have found that menstrual irregularities are more common in hypothyroid patients than hyperthyroid. Menorrhagia and polymenorrhagia is more common than amenorrhoea and oligomenorrhea in hypothyroid patients. Kakuno et al has concluded that patients with severe hyperthyroidism showed a higher prevalence of secondary amenorrhea $(2.5 \%)$ and hypomenorrhea $(3.7 \%)$ than those $(0.2 \%$ and $0.9 \%$, respectively) with mild or moderate hyperthyroidism. Moreover, patients with severe hypothyroidism had a higher prevalence $(34.8 \%)$ of menstrual disturbances than mild-moderate cases $(10.2 \%)$. This finding supports our study. ${ }^{8}$ Koutras et al have concluded that in hypothyroidism, on the contrary, polymenorrhea (increased menstrual bleeding) is more common which support our study. ${ }^{4}$ Güngör et al have concluded that the prevalence of menstrual disturbances in the other groups of thyroid dysfunction patients was not significantly different than that of controls which do not corroborates with our study. ${ }^{14}$

Regarding histopathological changes in endometrium in thyroid disorder patients' secretory endometrium was most common histological finding and was more common in hypothyroidism patients. This is supported by the study of Gorla et al. ${ }^{18}$

\section{CONCLUSION}

From this study we can conclude that most of the patients were in $3^{\text {rd }}$ and $4^{\text {th }}$ decade of life and married. It is more common in multiparous. Hypothyroidism is most common thyroid disorder followed by hyperthyroidism and subclinical hypothyroidism is least common. We have found that menstrual irregularities are more common in hypothyroid patients than hyperthyroid. Menorrhagia and polymenorrhagia is more common than amenorrhoea and oligomenorrhea in hypothyroid patients. Secretory endometrium was most common histopathological presentation.

Funding: No funding sources

Conflict of interest: None declared

Ethical approval: The study was approved by the Institutional Ethics Committee

\section{REFERENCES}

1. Omran AR, Standley CC. Family formation patterns and health, further studies: an International Collaborative Study in Columbia, Egypt, Pakistan, 
and the Syrian Arab Republic. Geneva: World Health Organization; 1981:271-302.

2. Nitika, Lohani P. Prevalence and determinants of menstrual disorders and napkin usage among women in India using DLHS-4 data. J Fam Med Prim Care. 2019;8(6):2106-11.

3. Von Basedow CA. Exophthalmos through hypertrophy of the cell tissue in the eye socket. Weekly Ges Heilkd. 1840;13:197.

4. Koutras DA. Disturbances of menstruation in thyroid disease. Ann NY Acad Sci. 1997;816:280-4.

5. Jacobson MH, Howards PP, Darrow LA, Meadows JW, Kesner JS, Spencer JB, et al. Thyroid hormones and menstrual cycle function in a longitudinal cohort of premenopausal women. Paediatr Perinat Epidemiol. 2018;32(3):225-34.

6. Doufas AG, Mastorakos G. The hypothalamicpituitary-thyroid axis and the female reproductive system. Ann NY Acad Sci. 2000;900:65-76

7. Ajmani NS, Sarbhai V, Yadav N, Paul M, Ahmad A, Ajmani AK. Role of thyroid dysfunction in patients with menstrual disorders in tertiary care center of Walled City of Delhi. J Obstet Gynaecol India. 2016;66(2):115-9.

8. Kakuno Y, Amino N, Kanoh M, Kawai M, Fujiwara M, Kimura M, et al. Menstrual disturbances in various thyroid diseases. Endocr J. 2010;57(12):1017-22.

9. Klein E, Kracht J, Krüskemper HL, Reinwein D, Scriba PC. Classification of thyroid diseases. Dtsch Med Wochenschr. 1973;98(47):2249-51.

10. Munro MG. Classification of menstrual bleeding disorders. Rev Endocr Metab Disord. 2012;13:22534.
11. Khatiwada S, Gautam S, KC R, Singh S, Shrestha S, Jha $\mathrm{P}$, et al. Pattern of thyroid dysfunction in women with menstrual disorders. Ann Clin Chem Lab Med. 2016;2(1):3-6.

12. Ramya MR, Parvarthavarthini, Sauvrey D, Sankareswari R. Menstrual disorders as sociated with thyroid dysfunction. Int J Reprod Contracept Obstet Gynecol. 2017;6:5113-7.

13. Sharma N, Sharma A.Thyroid profile in menstrual disorders. JK Science. 2012;14(1):14-17.

14. Güngör G, Hekimsoy Z, Öz D, Alarslan P, Hatiboglu $\mathrm{O}$, Özmen B. Menstrual disturbances in thyroid dysfunction. Endocr Abstracts. 2015;37:EP1048.

15. Padmaleela K, Thomas V, Lavanya KM, Kiranmai D. Thyroid disorders in dysfunctional uterine bleeding (DUB) among reproductive age group women-a cross-sectional study in a tertiary care hospital in Andhra Pradesh India. Int $\mathrm{J}$ Med Pharma Sci. 2013;4(1):41-6.

16. Pahwa S, Shailja G, Jasmine K. Thyroid dysfunction in dysfunctional uterine bleeding. J Adv Res Bio Sci. 2013;5(1):78-83.

17. Gorla P, Sanapala S, Devi E, Atla BL, Rasaputra M. Histopathology of endometrium in abnormal uterine bleeding, in correlation with thyroid profile and ultrasonography findings. Int $\mathrm{J}$ Res Med Sci. 2016;4:1463-9.

18. Verma SK, Pal A, Jaswal S. A study of thyroid dysfunction in dysfunctional uterine bleeding. Int $\mathbf{J}$ Reprod Contracept Obstet Gynecol. 2017;6:2035-9.

Cite this article as: Kothapalli D, Kolluru K. A prospective descriptive study of evaluation of menstrual disorders in thyroid dysfunction. Int J Reprod Contracept Obstet Gynecol 2021;10:2759-63. 